\title{
Effects of Different Land Use Systems on Selected Physico-Chemical Properties of Soils in Yamaltu, Yamaltu-Deba Local Government Area, Gombe State

\author{
Ibrahim, A. K*
}

Department of Soil Science, Federal University, Kashere, Gombe State, Nigeria

DOI: $10.36347 /$ sjavs.2020.v07i05.002

| Received: 23.04.2020 | Accepted: 03.05.2020 | Published: 12.05.2020

*Corresponding author: Ibrahim, A. K

Abstract

Original Research Article

Information about influence of different land use systems on soil physico-chemical properties is crucial for best land management practices. Properties of soil vary with land use system over time and the knowledge of these changes is vital for sustainable food productivity. The study was conducted at Yamaltu located in Yamaltu-Deba Local Government Area of Gombe State, Nigeria, with the objective to evaluate the influence of different land use types and soil depths on nutrient status and potential changes in nutrient contents due to land use activities. Three major land use systems namely rain fed arable land, irrigated arable land and orchard land were identified, described and mapped on bases of their soils. Six composites soil samples from $0-15 \mathrm{~cm}$ and $15-30 \mathrm{~cm}$ were collected from each landuse type and then air dried, ground and passed through a $2 \mathrm{~mm}$ sieve to determine physicochemical properties. Results of the experiment indicated that the soil were sandy clay loam in texture while Soil $\mathrm{pH}$ were slightly acidic to neutral under all landuse systems. In all landuse systems, organic carbon and total $\mathrm{N}$, available $\mathrm{P}$, exchangeable bases and CEC decreased with soil depth. The highest mean values of organic matter $\left(8.2\left(\mathrm{gkg}^{-1}\right)\right.$ and total nitrogen $\left(1.34 \mathrm{gkg}^{-1}\right)$ were recorded under the irrigated arable land while Available phosphorus $\left(26.2 \mathrm{mgkg}^{-1}\right)$, Calcium $\left(4.6 \mathrm{cmolkg}^{-1}\right)$, Magnesium $\left(0.50 \mathrm{cmolkg}^{-1}\right)$, Potassium $\left(0.26 \mathrm{cmolkg}^{-1}\right)$, Sodium $\left(0.21 \mathrm{cmolkg}^{-1}\right)$ and cation exchange capacity $\left(12.0 \mathrm{cCmolkg}^{-1}\right)$ were recorded under orchard land at the surface soil layer. From the results of the study it was possible to conclude that rain fed arable land and irrigated arable land had detrimental effects on the soil physicochemical properties. Therefore, reducing intensity of cultivation, adopting integrated soil fertility management and application of organic fertilizers could maintain the existing soil condition and replenish degraded soil properties.

Keywords: Land use types; Soil depths; food; fodder; fiber; fuel; degradation; socio-economic.

Copyright @ 2020: This is an open-access article distributed under the terms of the Creative Commons Attribution license which permits unrestricted use, distribution, and reproduction in any medium for non-commercial use (NonCommercial, or CC-BY-NC) provided the original author and source are credited.

\section{INTRODUCTION}

Rapid growth in population and long history of subsistence agriculture has changed the land use/land cover system and has been a major cause of environmental degradation on most parts of subSaharan Africa [1]. Amanze et al., [2] reported that, soil properties deteriorate with changes in land use especially from forest to arable. Different land-use system greatly influence physico-chemical properties and quality of soil [3] and affect the nutrient supply and uptake $[4,5]$. The increasing population and socioeconomic needs impart pressure on agricultural production system which ultimately results to unplanned changes in land-use systems [6]. So, it is a big deal to meet these necessities through balanced land-uses by keeping the soil fertility intact. Oguike and Mbagwu [7] opined that, changes in land use, such as conversion of natural forest to cropland, contributed to land degradation that manifested in losses of soil organic matter and total nitrogen. Chisci and Zanchi [8] stated that cropping results in loss of soil organic matter and reduced soil aggregate stability, increased bulk density and compaction. Agricultural activities changed the soil physical, chemical and biological properties, and play the major role for soil degradation mainly due to soil fertility decline as a result of lack of nutrient inputs. The rapid population growth demands more production of food, fodder, fiber and fuel from the land [9].

Intensive cultivation results in increase in sand fraction and bulk density, reduced soil nutrient status and water retention capacity while increasing soil acidity as against bush fallow land [10]. However, land restoration through bush fallow and conservation tillage could be effective in sequestering carbon and slowing down climate change [11]. Generally, a good 
understanding of land use and management effects on soil physical, chemical and biological provides an opportunity to evaluate sustainability of land use system [12]. There is increasing awareness that reduction in soil fertility from the agro ecosystem is a very widespread phenomenon and one of the crop production constraints. A change in land use, poor soil management, erosion and socioeconomic activities of the area can negatively lead to land degradation and loss of productivity. Loss of arable land due to intensive cultivation and erosion is a widespread problem in Nigeria. Low soil fertility was reported as one of the major factors affecting crop production in the study area $[13,14]$. The study area is facing with agricultural challenges such as inadequate of land for crop cultivation and livestock grazing, decline of soil fertility and rainfall variability resulting in low yield production, determining the physico-chemical property is crucial for further soil management and improvement. Therefore, the objective of the study was to evaluate the effects of different land use types on nutrient status and potential changes in nutrient contents due to land use activities.

\section{MATERIALS AND METHODS Study Area}

The study was conducted at Yamaltu located in Yamaltu-Deba Local Government Area of Gombe State, Nigeria. The study area is situated at the eastern part of Gombe metropolis on latitudes $10^{0} 14$ '17.3" North of the equator and longitudes $11^{0} 26^{\prime} 29.5$ " East of Greenwich meridian and about 282 metres above the sea level. It is in the Sudan Savannah zone of Nigeria covering a total land area of $1,981 \mathrm{~km}^{2}$. Its geomorphology comprises of greatly undulating plains and pediments [15]. The climate of the area is characterized by high temperatures and seasonal rainfall. The average annual rainfall of the area is between $800-900 \mathrm{~mm}$ with average temperatures ranges from $30-32^{\circ} \mathrm{C}$ and the area experience a relative humidity of 17-90 percent [15]. The area is characterized by dry sub humid zone [16]. The study area is divided into three land utilization types. The rain fed arable land which comprises of few trees like shearbutter, locust bean trees, and shrubs with scattered grasses and mainly cultivated with maize, sorghum, cowpea and vegetables. The orchard land is densely populated with mango, guava trees and few grasses. The land is relatively a flat land. The irrigated arable land is intensively cultivated all year round based on the information obtained from the farmers; it is relatively a flat land with scattered mango trees and dark coloured Vertisols soils. It is mainly cultivated with rice, maize, tomato, onion, pepper, okra and leafy vegetables. The soil fertility was managed by the application of both organic manure and inorganic fertilizer. Weed control was managed by both the application of herbicides and manual method of hoeing.

The farmers in the study area are practicing mixed farming system that is producing a variety of crops as well as rearing animals that improved the livelihoods of local communities and their income. All crops are annual and rain feed crops, such as maize, rice, sorghum, groundnut, cowpea, soybeans, sunflower and vegetables such as tomatoes, pepper, onion, okra, lettuce, cabbage, carrot are the common one. From the fruit, sugar cane, banana, mango, cashew, guava, and orange are found in some specific study area. The livestock of study area includes cattle, sheep, goats, poultry and equine (donkeys, camels, and horses).

\section{Site Selection for this study}

Yamaltu was purposively selected from Yamaltu-Deba LGA because higher land degradation and soil erosion problems are commonly observed in this area which has a deleterious impact on soil physical, chemical and biological properties under different land use types. Prior to the collection of soil samples, discussions was made with the community leaders in order to get the prehistory and current information about the utilization of land use types and lifestyle of the local community in the study area. During the discussion, enlightenment was also made as regard to the significance of the research in their area. Reconnaissance field survey was carried out in order to have a general view of land use types and also to collect information on landforms, vegetation, cropping history, topography and slope of the area, drainage characteristics, erosion hazard and general soil conditions in the study area. Then after, for addressing the intended objective, the treatments were stratified in to four land use types viz: cultivated, grazing, forest and grasslands.

\section{Soil sampling and preparation}

Four major land use types namely rain fed arable land, irrigated arable land and orchard land were used four this study. Six composites soil samples from $0-15 \mathrm{~cm}$ and $15-30 \mathrm{~cm}$ were collected from each landuse type and then air dried, ground and passed through a $2 \mathrm{~mm}$ sieve to determine physicochemical properties. A total of 36 composite samples were therefore collected from the three landuse types. 


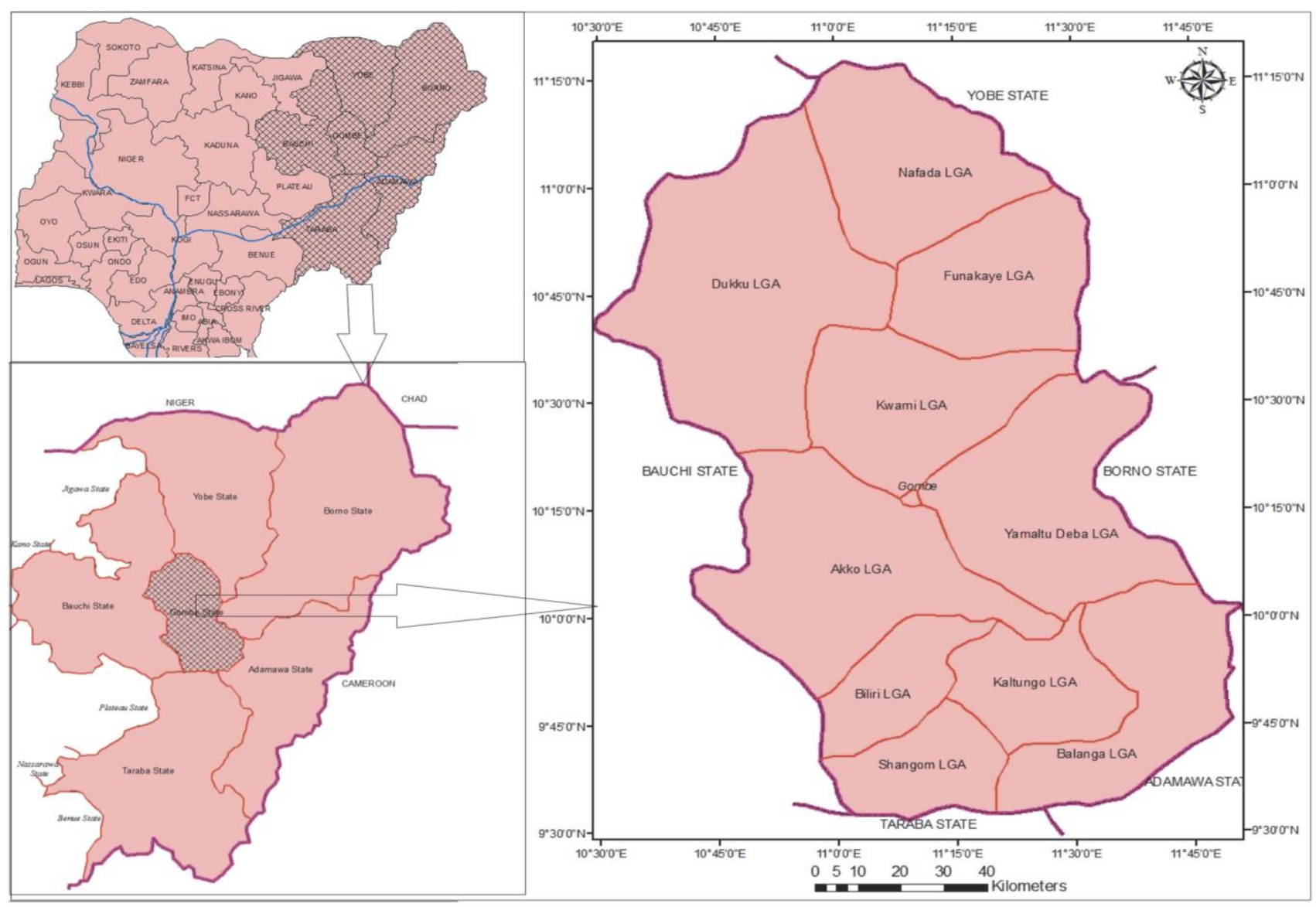

Fig-1: Map of Gombe State and Yamaltu-Deba local government area

\section{LABORATORY ANALYSES}

Soil $\mathrm{pH}$ of each soil sample was determined in water as described by McLean [17]. Total nitrogen was determined by the micro Kjeldahl method [18]. Organic carbon was determined by the Walkley-Black wet oxidation method of Nelson and Sommers [19]. Available phosphorus was determined by using Bray I extraction method [20]. While determining the cation exchange capacity (CEC) by ammonium acetate method $\left(\mathrm{NH}_{4} \mathrm{OAC}\right)$. $\mathrm{NH}_{4} \mathrm{OAC}$ extract was saved and analyzed for exchangeable cations were calcium and magnesium was read using atomic absorption spectrophotometer (AAS), whereas exchangeable sodium and potassium were read using flame photometer as described by Page et al., [18].

\section{RESULTS AND DISCUSSION}

The physical properties of soils in the studied area were presented in Table-1. The particle sizes in the three land uses were dominated by sand fraction irrespective of land use system. In the surface soil layer $(0-15 \mathrm{~cm}$ depth) under different land use systems, the sand fractions ranges from 49.0-51.0\% (50\% average), Silt fractions ranged from $23-26 \% \quad(24.3 \%$ average)while clay fractions ranged from $25-27 \%$ (25.7\% average). In the subsurface soil layer $(15-30 \mathrm{~cm}$ depth) the sand fractions ranges from $40.0-42.0 \%(41 \%$ average), Silt fractions ranged from $27-28 \%(27.7 \%$ average) while clay fractions ranged from $31-32 \%$ (31.3\% average) respectively. Oguike and Mbagwu [7], Attributed the high sand fractions in the area to parent material since the texture of the soil is highly influenced by the parent material and topography over time. Generally, the clay content was higher in the subsurface soil layer of irrigated arable land and rain fed arable land as compared to the adjacent orchard land. The reason could be due to the preferential removal of clay particles and its downward movement into the subsurface soil layer through the process of clay migration. Similarly, Chemada et al., [21] attributed the increased clay content of irrigated arable land and rain fed arable land from the surface to subsurface to the long period of cultivation. The current result is in agreement with the findings of Shiferaw [22]; Mengistu et al., [23] who reported an increase in clay content with depth under cultivated lands due to long period of cultivation. 
Table-1: Textural class of different land use types at 0-15 and $15-20 \mathrm{~cm}$ depth

\begin{tabular}{|l|l|l|l|l|}
\hline Land use & Sand (\%) & Silt (\%) & Clay (\%) & Soil Texture \\
\hline Surface layer $(0-15 \mathrm{~cm})$ & & & & \\
\hline Rain fed arable land & 51 & 24 & 25 & \\
\hline Irrigated arable land & 49 & 26 & 25 & \\
\hline Orchard land & 50 & 23 & 27 & \\
\hline Mean & 50 & 24.3 & 25.7 & \\
\hline Subsurface layer $(15-30 \mathrm{~cm})$ & & & & \\
\hline Rain fed arable land & 42 & 27 & 31 & \\
\hline Irrigated arable land & 41 & 31 & 28 & \\
\hline Orchard land & 40 & 28 & 32 & \\
\hline Mean & 41 & 27.7 & 31.3 & \\
\hline
\end{tabular}

\section{Effect of land use on soil pH}

The result on soil $\mathrm{pH}$ was presented in Table2. Soils under all the three land uses were moderately acidic to neutral as rated by Black [24] $(\mathrm{pH}$ ranges from 5.6-6.9 irrespective of land uses and depths). Lowest values were recorded in irrigated arable land in both surface and sub-surface layers of soil in terms of soil $\mathrm{pH}$. In the surface layer $(0-15 \mathrm{~cm})$ under different land use systems, the $\mathrm{pH}$ value ranges from 6.4-6.9 (6.6 average) which was rated slightly acidic to neutral as rated by Black [24]. In the subsurface layer the $\mathrm{pH}$ value varied from 5.6-6.3 (6.0averages) which was also rated moderately acidic to slightly acidic as rated by Black [24] (Table-2). The slightly acidic condition of the irrigated arable land is due to organic and inorganic fertilizer application by the farmers. These results are in agreement with the results of Takele et al., [25] who suggested that the soil reaction was lower under cultivated land compared to forest and grazing lands at soil surface $(0-20 \mathrm{~cm}$ depth). The slightly acidic to neutral $\mathrm{pH}$ of the soils agreed with the findings of $[26$, 14] who worked with similar soils. The values obtained in the study are within the $\mathrm{pH}$ requirement for most arable crops for nutrient up take.

\section{Effect of land use on Soil organic carbon}

The result on soil organic carbon content was presented in Table-2. In the surface layer under different land use systems, the soil organic carbon ranges from $7.4-8.2 \mathrm{gkg}^{-1}$ (7.73 $\mathrm{gkg}^{-1}$ average) which was rated low as rated by Esu [27]. In the subsurface layer, the SOC varied between $6.8-7.9 \mathrm{gkg}^{-1}\left(7.23 \mathrm{gkg}^{-}\right.$ ${ }^{1}$ average) which was also rated low as rated by Esu [27] (appendix-1). The low SOC may be partly due to effect of land use activities and high temperature which favours rapid mineralization of organic matter [28]. This finding is in agreement with different individuals' findings Ibrahim [29], Iqbal et al., [30], Takele et al., [25] and Mondal et al., [31] in which they reported that the soil organic carbon decrease with increasing soil depth, with more accumulation on the surface soil layer. Higher amount of organic carbon accumulation under orchard land may be due to stems, barks, flowers, leaf litter fall in the surface and through root deposition and logs microorganisms in deeper layers [32]. On the other hand, the low soil organic carbon in rain fed arable land and irrigated arable land may be due to the removal of biomass during cultivation, a low quantity and quality carbon inputs to the soil combined with faster organic matter decomposition and mineralization rates [4, 33]. Moreover, intensive cultivation, tillage and several management practices hastens the loss of SOC through facilitating microbial activities and the process of oxidation [34].

\section{Effect of Land Use on Total N}

The result on total nitrogen was presented in Table-1. In the surface layer under different land use systems, the total nitrogen content ranges from 1.26$1.34 \mathrm{gkg}^{-1}\left(1.3 \mathrm{gkg}^{-1}\right.$ average $)$ which was rated low as rated by Esu [27] (appendix-1). In the subsurface layer, the total nitrogen value varied between 1.16-1.23 $\mathrm{gkg}^{-1}$ (1.19 $\mathrm{gkg}^{-1}$ average) which was also rated low as rated by Esu [27] (appendix-1). The highest value of $1.34 \mathrm{gkg}$ 1 was recorded under orchard land while the lowest value of 1.22 and $1.26 \mathrm{gkg}^{-1}$ was recorded under irrigated arable land and rain fed arable land. Higher amount of total $\mathrm{N}$ accumulation under orchard land might be due to the micro climate created by adequate vegetation cover which moderated the soil temperature, air and moisture against total $\mathrm{N}$ loss by volatilization. On the other hand, the relatively low value of total $\mathrm{N}$ observed under irrigated arable land and rain fed arable land might be due to the volatilization of nitrogen resulting from increased oxidation of nitrogenous compounds in the soil [35]. This might have been triggered by high exposure of the soil to air and increased temperature by frequent tillage operations. However, Chikamnele et al., [35] stated that the increased mobility of nitrogen caused by incessant pulverization of the soil possibly resulted to losses by leaching. Similar result were reported by Oguike and Mbagwu [7] they explain that continuous cultivation of soils caused a substantial loss of nitrogen due to increased volatilization and leaching effects.

\section{Effect of Land Use on Available P}

The result on available phosphorus was presented in Table-2. In the surface layer under different land use systems, available phosphorus content value ranges from $18.9-26.2 \mathrm{mgkg}^{-1}$ (22.6 $\mathrm{mgkg}^{-1}$ average) which was rated medium to high as rated by Esu [27] (appendix-1). In the subsurface layers, the available phosphorus value varied between 12.8- 
$19.7 \mathrm{mgkg}^{-1}$ (16.6 $\mathrm{mgkg}^{-1}$ average) which was also rated medium as rated by Esu [27] (appendix-1). On the other hand, highest concentration of available $\mathrm{P}$ was recorded under irrigated arable land $\left(26.2 \mathrm{mg} \mathrm{kg}^{-1}\right)$ followed by rain fed arable land $\left(24.7 \mathrm{mg} \mathrm{kg}^{-1}\right)$ and orchard land $\left(18.9 \mathrm{mg} \mathrm{kg}^{-1}\right)$ whereas the subsurface soil layer of 15 $30 \mathrm{~cm}$ depth followed a similar trend of irrigated arable land $\left(19.7 \mathrm{mg} \mathrm{kg}^{-1}\right.$ ) followed by rain fed arable land (17.2 $\mathrm{mg} \mathrm{kg}^{-1}$ ) and orchard land (12.8 $\mathrm{mg} \mathrm{kg}^{-1}$ ). Decrease in $\mathrm{P}$ content with depth was a common trait in all three land-uses. Better values of available $P$ content in irrigated arable land and rain fed arable land may be due to long-term application of phosphates fertilizers and addition of organic manures that increase $P$ availability [36]. Hishe et al., [37] stated that, the presence of phosphorus content in soils depends upon a number of factors such as climate, vegetation, soil texture, land use pattern, fertilizer use, drainage, irrigation, and soil $\mathrm{pH}$, whereby the availability of phosphorus is greatest in the soil $\mathrm{pH}$ range 6.0-6.5.This result is in agreement with the findings reported by Nega [38] who stated that soil available $P$ was significantly affected by land use types.

\section{Effect of Land Use on Calcium}

The result of exchangeable calcium was presented in Table-2. In the surface layer of the soil under different land use system, the value of the exchangeable calcium ranges from $3.6-4.6 \mathrm{cmolkg}^{-1}$ $\left(4.2 \mathrm{cmolkg}^{-1}\right.$ average) which was rated medium as rated by Esu [27] (appendix-1). In the subsurface soil layer, the calcium content varied between $1.6-2.2 \mathrm{cmolkg}^{-1}$ (1.97 $\mathrm{cmolkg}^{-1}$ average) which was rated low to medium as rated by Esu [27] (appendix-1). Based on the data recorded in the study area, the exchangeable $\mathrm{Ca}$ was higher at the surface soil depth than at the subsurface soil depth (Table-2). This could be the possibility of the high exchangeable $\mathrm{Ca}$ was available on surface soil layer with an abundance of animal and plant residues than beneath the soil layer. The present study was in contradicted the findings of Bore and Bedadi [39] who reported that exchangeable $\mathrm{Ca}$ increased with increasing soil depth since it is susceptible and possibility of easily leach downward by runoff and water percolation. On the other hand, the present study corroborates with the findings of Ibrahim [40]; Kiflu and Beyene [41] who reported that, the exchangeable $\mathrm{Ca}$ contents was higher on the surface soil layer than the subsurface soil layer due to the association of biological accumulation with biological activity and accumulation from plant residues.

\section{Effect of Land Use on Magnesium}

The result of exchangeable magnesium was presented in Table-2. In the surface soil layer exchangeable magnesium ranges from $0.34-0.50$ $\mathrm{cmolkg}^{-1}$ (0.42 $\mathrm{cmolkg}^{-1}$ average $)$ which was rated medium as rated by Esu [27] (appendix-1). In the subsurface soil layer, the magnesium varied between $0.31-0.42 \mathrm{cmolkg}^{-1}\left(0.38 \mathrm{cmolkg}^{-1}\right.$ average $)$ and was also rated medium as rated by Esu [27] (appendix-1). This result agrees with Ibrahim et al., [42] who reported that calcium and magnesium are the predominant basic cations in soils in the study area. The highest $(0.50$ $\mathrm{cmolkg}^{-1}$ ) exchangeable $\mathrm{Mg}$ was recorded on the surface soil layer of irrigated arable land while the lowest $\left(0.31 \mathrm{cmolkg}^{-1}\right)$ exchangeable $\mathrm{Mg}$ was obtained under the subsurface soil layer of orchard land (Table2).

\section{Effect of Land Use on Potassium}

The result on exchangeable potassium was presented in Table-2. In the surface soil layer exchangeable potassium ranges from $0.21-0.26 \mathrm{cmolkg}$ ${ }^{1}$ ( $0.24 \mathrm{cmolkg}^{-1}$ average) which was rated medium as rated by Esu [27] (appendix-1). In the subsurface soil layer, exchangeable potassium values varied between $0.13-0.19 \mathrm{Cmolkg}^{-1}\left(0.16 \mathrm{cmolkg}^{-1}\right.$ average $)$ which was also rated low to medium as rated by Esu [27] (appendix-1). This result contradicted with the previous findings of Ibrahim et al., [40] who reported higher potassium content and attributed it to the nature of irrigation water which contained high amount of potassium. The highest $\left(0.26 \mathrm{cmolkg}^{-1}\right)$ and the lowest $\left(0.13 \mathrm{cmolkg}^{-1}\right)$ exchangeable $\mathrm{K}$ contents were recorded at the surface layers of the irrigated arable land and the subsurface layers of the orchard land, respectively (Table-2). The low exchangeable $\mathrm{K}$ contents observed under irrigated arable land and rain fed land are due to continuous cultivations and continues use of inorganic fertilizers which enhances the loss of base cations through erosion, crop harvest and leaching in the study area which is supported by previous findings of Malo et al., [43]; Mengistu et al., [23] who indicate that intensity of weathering, cultivation and use of acid forming inorganic fertilizers affect the distribution of $\mathrm{K}$ in the soil system and enhance its depletion.

\section{Effect of Land Use on Sodium}

The result of exchangeable sodium was presented in Table-2. In the surface soil layers exchangeable sodium ranges from $0.15-0.21 \mathrm{cmolkg}^{-1}$ $\left(0.17 \mathrm{cmolkg}^{-1}\right.$ average $)$ which was rated low to medium as rated by Esu [27] (appendix-2). In the subsurface horizons, the sodium content varied between 0.17 $0.23 \mathrm{cmolkg}^{-1}\left(0.19 \mathrm{cmolkg}^{-1}\right.$ average $)$ which was also rated low to medium as rated by Esu [27] (appendix-1). The highest Sodium content was recorded at the subsurface soils of rain fed arable land and irrigated arable land which could be attributed to leaching of basic cation down the profile Mengistu et al., [23]. This study corroborates the findings of Mengistu et al., [23] who reported higher exchangeable $\mathrm{Na}$ under subsurface soil layer (15-30cm depth).

\section{Effect of Land Use on CEC}

The result on cation exchange capacity was presented in Table-2. In the surface soil layers of the soils cation exchange capacity ranges from 9.11-12 $\mathrm{cmolkg}^{-1}$ (10.44 $\mathrm{cmolkg}^{-1}$ average) which was rated 
medium as rated by Esu [27] (appendix-1). In the subsurface soil layers, the cation exchange capacity content varied between $8.2-8.6 \mathrm{cmolkg}^{-1}\left(8.03 \mathrm{cmolkg}^{-}\right.$ ${ }^{1}$ average) which was also rated medium as rated by Esu [27] (appendix-2). CEC values decreased from the surface to the subsurface layer under different land use types. Generally, the surface soils of irrigated arable land had the highest value of CEC $\left(12 \mathrm{cmolkg}^{-1}\right)$ which could be attributed to difference in soil organic matter and clay content under different land use types, which is in agreement with the findings of [23, 44].

Table-2: The effect of land use types and depth on Organic C, Total N $\left(\mathrm{gkg}^{-1}\right)$, Available P $\left(\mathrm{mgkg}^{-1}\right) \mathrm{and}^{-}$ Exchangeable bases and CEC $\left(\mathrm{Cmolkg}^{-1}\right)$

\begin{tabular}{|l|l|l|l|l|l|l|l|l|l|}
\hline Land use & Soil $\mathbf{~ p H}$ & $\mathbf{O C}$ & $\mathbf{T N}$ & $\mathbf{A P}$ & $\mathbf{C a}$ & $\mathbf{M} \mathbf{g}^{\mathbf{2 +}}$ & $\mathbf{K}^{+}$ & $\mathbf{N a}^{+}$ & $\mathbf{C E C}$ \\
\hline Surface layer & & & & & & & & & \\
\hline Rain fed arable land & 6.6 & 7.4 & 1.26 & 24.7 & 4.3 & 0.34 & 0.25 & 0.17 & 10.2 \\
\hline Irrigated arable land & 6.9 & 8.2 & 1.34 & 18.9 & 3.6 & 0.41 & 0.21 & 0.15 & 9.11 \\
\hline Orchard land & 6.4 & 7.6 & 1.22 & 26.2 & 4.6 & 0.50 & 0.26 & 0.21 & 12.0 \\
\hline Mean & 6.6 & 7.7 & 1.30 & 22.6 & 4.2 & 0.42 & 024 & 0.17 & 10.44 \\
\hline Subsurface layer & & & & & & & & & \\
\hline Rain fed arable land & 5.9 & 6.8 & 1.18 & 17.2 & 2.1 & 0.34 & 0.17 & 0.25 & 8.2 \\
\hline Irrigated arable land & 6.3 & 7.9 & 1.23 & 12.8 & 1.6 & 0.31 & 0.13 & 0.17 & 7.2 \\
\hline Orchard land & 5.6 & 7.0 & 1.16 & 19.7 & 2.2 & 0.42 & 0.19 & 0.23 & 8.6 \\
\hline Mean & 6.0 & 7.2 & 1.19 & 16.6 & 1.97 & 0.38 & 0.16 & 0.19 & 8.03 \\
\hline
\end{tabular}

Appendix 1: Ratings for soil fertility classes

\begin{tabular}{|l|l|l|l|}
\hline Parameter & Low & Medium & High \\
\hline Oc gkg $^{-1}$ & $<10$ & $10-15$ & $>15$ \\
\hline Total N gkg & $<1.5$ & $1.5-2.0$ & $>.2 .0$ \\
\hline Available P mgkg & $<10$ & $10-20$ & $>20$ \\
\hline $\mathrm{Ca}^{2+} \mathrm{cmol} \mathrm{kg}^{-1}$ & $<2$ & $2-5$ & $>5$ \\
\hline $\mathrm{Mg}^{2+} \mathrm{cmol} \mathrm{kg}^{-1}$ & $<0.3$ & $0.3-1.0$ & $>1.0$ \\
\hline $\mathrm{K}^{+} \mathrm{cmol} \mathrm{kg}$ & $<0.15$ & $0.15-0.30$ & $>0.30$ \\
\hline $\mathrm{Na}^{+} \mathrm{cmol} \mathrm{kg}$ & $<0.2$ & $0.2-0.3$ & $>0.3$ \\
\hline CEC cmol kg & $<6.0$ & $6.0-12$ & $>12$ \\
\hline
\end{tabular}

Source: Esu (1991) [27]

Adapted from Ibrahim et al., (2010) [40]

Appendix 2: Soil Reaction $(\mathbf{p H})$ Ratings
\begin{tabular}{|l|l|}
\hline Soil reaction & $(\mathrm{pH})$ \\
\hline Extremely acid & 4.5 \\
\hline Very strongly acid & $4.6-5.0$ \\
\hline Strongly acid & $5.1-5.5$ \\
\hline Moderately acid & $5.6-6.0$ \\
\hline Slightly acid & $6.1-6.5$ \\
\hline Neutral & $6.6-7.3$ \\
\hline Slightly alkaline & $7.4-7.8$ \\
\hline Moderately alkaline & $7.9-8.4$ \\
\hline Strongly alkaline & $8.5-9.0$ \\
\hline Very strongly alkaline & $>9.0$ \\
\hline \multicolumn{2}{|c|}{ Source: Black (1965) [24] } \\
Adapted from Mamzing et al., (2014) [45]
\end{tabular}

\section{CONCLUSION}

In all landuse systems, organic carbon and total $\mathrm{N}$, available $\mathrm{P}$, exchangeable bases and CEC decreased with soil depth. The highest mean values of organic matter $\left(8.2\left(\mathrm{gkg}^{-1}\right)\right.$ and total nitrogen $\left(1.34 \mathrm{gkg}^{-1}\right)$ were recorded under the irrigated arable land while Available phosphorus $\left(26.2 \mathrm{mgkg}^{-1}\right)$, Calcium (4.6 cmolkg $\left.{ }^{-1}\right)$, Magnesium ( $\left.0.50 \mathrm{cmolkg}^{-1}\right)$, Potassium (0.26 cmolkg $\left.{ }^{-1}\right)$, Sodium $\left(0.21 \mathrm{cmolkg}^{-1}\right)$ and cation exchange capacity $\left(12.0 \mathrm{cmolkg}^{-1}\right)$ were recorded under orchard land at the surface soil layer. From the results of the study it was possible to conclude that rain fed arable land and irrigated arable land had detrimental effects on the soil physico-chemical properties. Therefore, reducing intensity of cultivation, adopting integrated soil fertility management and application of organic fertilizers could maintain the existing soil condition and replenish degraded soil properties.

\section{REFERENCE}

1. Feoli E, Vuerich LG, Woldu Z. Processes of environmental degradation and opportunities for rehabilitation in Adwa, Northern Ethiopia. Landscape ecology. 2002 Dec 1;17(4):315-25.

2. Amanze CT, Paul CO, Eneje RC. Land Use Effects on Some Physico-Chemical Properties of Ultisol at Ndume-Ibeku, Southeastern Nigeria. International Journal of Scientific and Research Publications. 2017, 9(7), 7-19.

3. Paz-Kagan T, Shachak M, Zaady E, Karnieli A. A spectral soil quality index (SSQI) for characterizing soil function in areas of changed land use. Geoderma. 2014 Oct 1;230:171-84.

4. Murty D, Kirschbaum MU, Mcmurtrie RE, Mcgilvray $H$. Does conversion of forest to agricultural land change soil carbon and nitrogen? A review of the literature. Global change biology. 2002 Feb;8(2):105-23.

5. Jiang Y, Zhang YG, Zhou D, Qin Y, Liang WJ. Profile distribution of micronutrients in an aquic brown soil as affected by land use. Plant, Soil and Environment. 2009 Nov 11;55(11):468-76.

6. Seto KC, Woodcock CE, Song C, Huang X, Lu J, Kaufmann RK. Monitoring land-use change in the Pearl River Delta using Landsat TM. International Journal of Remote Sensing. 2002 Jan 1;23(10):1985-2004. 
7. Oguike PC, Mbagwu JS. Variations in some physical properties and organic matter content of soils of coastal plain sand under different land use types. World journal of agricultural sciences. 2009;5(1):63-9.

8. Chisci G, Zanchi C. The influence of different tillage systems and crops on soil loss on hilly Silt Clay soil. In: Soil conservation; problems and prospects, R.P.C Morgan (Ed). John Wiley, N Y., 1981; 211-217.

9. Selassie YG, Ayanna G. Effects of different land use systems on selected physico-chemical properties of soils in Northwestern Ethiopia. Journal of agricultural science. 2013 Apr 1;5(4):112-120.

10. Malgwi WB, Abu ST. Variation in some physical properties of soils formed on a hilly terrain under different land use types in Nigerian Savanna. International Journal of Soil Science. 2011 Jul 1;6(3):150-63.

11. Holland JM. The environmental consequences of adopting conservation tillage in Europe: reviewing the evidence. Agriculture, ecosystems \& environment. 2004 Jun 1;103(1):1-25.

12. Bewket W. Towards integrated watershed management in highland Ethiopia: the Chemoga watershed case study. 2003.

13. Ibrahim AK, Yakubu H, Askira MS. Assessment of heavy metals accumulated in wastewater irrigated soils and lettuce (Lactuca sativa) in Kwadon, Gombe State Nigeria. AmericanEurasian Journal of Agricultural \& Environmental Sciences. 2014;14(6):502-8.

14. Ibrahim $\mathrm{AK}$, Salem A. Content of $\mathrm{Cd}, \mathrm{Cr}$ and $\mathrm{Pb}$ in Soil and Amaranthus caudatus Grown in Yamaltu-Deba Local Government Area, Gombe State, Nigeria International Journal of Plant \& Soil Science, 2017;16(3):1-8.

15. Ibrahim AK, Abubakar B. Extractable Micronutrients Status in Relation to other Soil Properties in Jangargari, Yamaltu-Deba Local Government Area, Gombe State. Asian Journal of Agriculture and Food Sciences. 2013 Dec 12;1(5):219-221.

16. Ojanuga AG. Agroecological zones of Nigeria manual. FAO/NSPFS, Federal Ministry of Agriculture and Rural Development, Abuja, Nigeria. 2006;124.

17. Mclean ED. Soil $\mathrm{pH}$ and Lime Requirements. In Page A.L. (2nd Ed). Methods of Soil Analysis Part 2. Chemical and Microbiological Properties (2nd Ed.). Agronomy series No. SSSA. Madison, Wis. USA. 1982; 199-234,

18. Page AL, Miller RH, Keeney DR. Methods of Soil Analysis, Part- 2. 2nd Edn. American. Soc. Agron. Inc. Madison, Washington, USA. 1982;98-765.

19. Nelson DW, Sommers LE. Total carbon, organic carbon and organic matter. In: AL RH Miller, DR Keeney (Eds.), Methods of Soil Analysis, Part 2; Chemical and Microbiological Properties,
American Society of Agronomy: Madison. 1982;539-579.

20. Bray RH, Kurtz LT. Determination of total organic and available forms of phosphorus in soils. Soil Science, 1945;59:39-45.

21. Chemada $\mathbf{M}$, Kibret $\mathrm{K}$, Fite $\mathrm{T}$. Influence of different land use types and soil depths on selected soil properties related to soil fertility in Warandhab Area, Horo Guduru Wallaga Zone, Oromiya, Ethiopia. International Journal of Environmental Sciences and Natural Resources, 2017;4(2):555-634.

22. Shiferaw B. Soil phosphorous fractions influenced by different cropping system in Andosols and Nitisols in Kambata- Tenbaro and Wolaita Zones, SNNPRS, Ethiopia. MSc Thesis Submitted to School of Graduate Studies, Alemaya University, Ethiopia, 2004;126.

23. Mengistu C, Kibebew K, Tarekegn F. Influence of Different Land Use Types and Soil Depths on Selected Soil Properties Related to Soil Fertility in Warandhab Area, Horo Guduru Wallaga Zone, Oromiya, Ethiopia. International Journal of Environmental Sciences \& Natural Resources, 2017;4(2):555634.

24. Black CA. Methods of Soil Analysis. Sponsored by the American Society of Agronomy and the American Society for Testing Materials. American Society for agronomy, 1965.

25. Takele L, Chimdi A, Abebaw A. Dynamics of Soil fertility as influenced by different land use systems and soil depth in West Showa Zone, Gindeberet District, Ethiopia. Agriculture, Forestry and Fisheries, 2014;3(6):489-494.

26. Ibrahim AK, Umar AH. Profile Distribution of Micronutrients in Jangargari, Yamaltu-Deba Local Government Area, Gombe State. Journal of Applied Phytotechnology in Environmental Sanitation, 2012;1(2):83-89.

27. Esu IE. Detailed Soil Survey of NIHORT Farm at Bankure, Kano State, Nigeria Institute of Agricultural Research, ABU Zaria. 1991.

28. Fasina AS. Characteristics, Classification and Management of Soils of Lagos State. In: Babalola O, Omoti U, Isenmila AE. (eds), Management of the soil resources of Nigeria for sustainable agricultural production in the 21 st century, pp. 33 38. Proc. of the 25th Annual Conference of Soil Science Society of Nigeria, held at Precious Palm Royal Hotel, Benin city, Edo State, Nigeria. 21st 29th Nov. 1999.

29. Ibrahim MM, Damasceno A. Hypertension in developing countries. The Lancet. 2012 Aug 11;380(9841):611-9.

30. Iqbal M, Khan AG, Hassan AU, Amjad M. Soil physical health indices, soil organic carbon, nitrate contents and wheat growth as influenced by irrigation and nitrogen rates. International Journal of Agriculture and Biology, 2012;14:20-28. 
31. Mandal A, Too ASR, Dhaliwal SS. Effect of Land-uses on Physico-Chemical Properties and Nutrient Status of Surface $(0-15 \mathrm{~cm})$ and SubSurface $(15-30 \mathrm{~cm})$ Layers in Soils of SouthWestern Punjab, India. International Journal of Current Microbiology and Applied Sciences 2018;7(06): 2659-2671.

32. Zhou Z, Wang C. Soil - microbe - mineralization carbon and nitrogen stoichiometry under different land-uses in the Maoershan region. Acta Ecologica Sinica, 2017;37:1-9.

33. Wang Q, Liu J, Wang Y, Guan J, Liu Q, Lv DA. Land use effects on soil quality along a native wetland to cropland chronosequence. European journal of soil biology. 2012 Nov 1;53:114-20.

34. Sharma V, Hussain S, Sharma KR, Ary, VK. Labile carbon pools and soil organic carbon stocks in foothill Himalayas under different land use systems. Geoderma, 2014;232-234:81-87.

35. Chikkanna S, Naik MK, Amaresh YS, Jayalakshmi SK. Prevalence of Emerging Disease of Macrophomina Stem Canker of Pigeonpea in North Eastern Karnataka, India. Environment \& Ecology. 2017 Apr;35(2C):1323-6.

36. Mohammadi S, Kalbasi M, Shariatmadari $H$. Cumulative and residual effects of organic fertilizer application on selected soil properties, water soluble $\mathrm{P}$, Olsen-p and $\mathrm{P}$ sorption index. Journal of Agricultural Science and Technology, 2009; 11: 487-497.

37. Hishe S, Lyimo J, Bewket W. Soil and water conservation effects on soil properties in the Middle Silluh Valley, northern Ethiopia. International Soil and Water Conservation Research. 2017 Sep 1;5(3):231-40.

38. Emiru N, Gebrekidan H. Effect of land use changes and soil depth on soil organic matter, total nitrogen and available phosphorus contents of soils in Senbat Watershed, Western Ethiopia. ARPN Journal of Agricultural and Biological Science. 2013;8(3):206-12.

39. Bore G, Bedadi B. Impacts of land use types on selected soil physico-chemical properties of Loma Woreda, Dawuro Zone, Southern Ethiopia. Science, Technology and Arts Research Journal. 2015;4(4):40-8.

40. Ibrahim AK. Fertility and salinity/sodicity assessment of some Fadama soils in Yamaltu, Gombe State. Nigerian Journal of Research in Agriculture, 2010, (7):1 69-74.

41. Kiflu A, Beyene S. Effects of different land use systems on selected soil properties in South Ethiopia. Journal of Soil Science and Environmental Management. 2013;4(5):100-7.

42. Ibrahim S. Poverty, aspirations and well-being: Afraid to aspire and unable to reach a better lifevoices from Egypt. Brooks World Poverty Institute Working Paper. 2011(141).

43. Malo DD, Schumacher TE, Doolittle JJ. Longterm cultivation impacts on selected soil properties in the northern Great Plains. Soil and Tillage Research. 2005 Apr 1;81(2):277-91.

44. Hayatu NG, Samuel CD, Sale A, Abdullahi IL, Sharu MB, Buji I, Nabayi A, Haruna FD, Sharif RM. Effect of Land Use Systems on Selected Chemical Properties of Soils in Gidan Sule, Wamakko, Sokoto State, Nigeria. International Journal of Research and Innovation in Applied Science, (8):1118-22.

45. Mamzing D, Loks NA, Manggoel W, Gojing SB, Ashom SA. Assessment of some micronutrient ( $\mathrm{Zn}$ and $\mathrm{Cu}$ ) status of fadama soils under cultivation in Bauchi, Nigeria. Journal of Biology, Agriculture and Healthcare. 2014;4(24):147-51. 